\title{
The Julian Alps UNESCO Biosphere Reserve
}

\author{
Majda Odar, Renata Cerkovnik, Mojca Smolej, Marko Pretner, Davorin Koren, Janez Bizjak, Klemen Lan- \\ gus, Miša Novak \& Slavka Zupan
}

Keywords: UNESCO MAB, Triglav National Park, Julian Alps Biosphere Reserve, identity, management, networking, education, sustainable development, depopulation, wellbeing

\section{Abstract}

The year 2023 will mark the $20^{\text {th }}$ anniversary of the proclamation of the Julian Alps Biosphere Reserve (JABR). When awarded the prestigious title, the Triglav National Park (TNP) Authority was already the managing body of TNP, which constitutes the core and buffer zones of the then-newly designated area. Over the course of time, it has become clear that buffer zone management is instrumental in securing the objectives of the TNP and JABR. This paper discusses aspects of management relating mostly to visitation, education and training, cross-border cooperation, and enhancing the local economy through the collaboration of providers. A bottom-up approach and multi-stakeholder networking as essential components of modern policy-making are the key to success, particularly since sustainable development in sensitive areas is reliant upon fostering a strong and broad community identity and local support for protected areas.

\section{Profile}

Protected area

Triglav National Park

\& Julian Alps Bios-

phere Reserve

Mountain range

Alps, Slovenia

\section{The Julian Alps and Triglav National Park - a single area of shared geography and identity}

On 10 July 2003, the UNESCO office in Paris adopted a Decision to include the Julian Alps, Triglav National Park (TNP) (see link in the References for Triglav National Park) and part of the Karavanke mountains in the international network of UNESCO Man and the Biosphere (MAB) Reserves. The Julian Alps thus became part of a world network of model regions of sustainable development. The application was submitted by the TNP Authority, the long-term manager of Slovenia's only protected area of national importance, in cooperation with the Slovenian $\mathrm{Na}$ tional Commission for UNESCO. When the park was included in the MAB network, the TNP Authority was nominated as the administrative authority of the Julian Alps BR. ${ }^{1}$

\section{Presentation, location and municipalities}

The Julian Alps Biosphere Reserve (JABR) is located in the north-east of Slovenia and covers the high-altitude mountains of the Julian Alps, the northwestern part of the Karavanke range, and the Julian Pre-alps (Prealpi Giulie). It extends to the state border with Italy (see Figure 1). The area is characterized by outstanding biodiversity and landscape features, and a rich cultural heritage.

UNESCO uses biosphere reserve as the official term. Because reserve may be understood as a protected area which excludes people, the term has been translated into Slovene as območje (area or region).
The JABR comprises 10 municipalities: Bled, Bohinj, Jesenice, Radovljica, Žirovnica, Kranjska Gora, Gorje, Bovec, Kobarid and Tolmin. In terms of management regimes, there are three zones: the core zone, the buffer zone, and the transition area. The core and buffer zones of the biosphere reserve (BR) coincide with the same designation zones of TNP, which falls entirely within the MAB network, whilst the transition area provides supporting functions to the core and buffer zones. The transition area also has an important influence on the core zone. The management modela single administrative authority to manage both the protected area and the BR - has several advantages, since it ensures that nature protection and sustainability measures are coordinated throughout the planning and implementation processes. The model has been effective in establishing new tourist offers located both within and outside the TNP area (e. g. the Juliana Trail), although coordinated management does require the active engagement of other stakeholders with regard to some issues, such as the management of state roads. The legal framework for the involvement of stakeholders is found in the TNP Management Plan 2016-2025, which was based on the TNP Act (see Načrt upravljanja Triglavskega narodnega parka 2016-2025). The TNP Management Plan comprises the following general chapters: nature conservation, preservation of cultural heritage, sustainable development, visitation, and management and administration.

\section{Vignette 1: The Julian Alps BR in figures}

Surface area: 195723 ha (11\% of Slovenia's territory), population 83517 (2019). A recent survey shows that the population is declining slightly $(-1 \%$ in the 


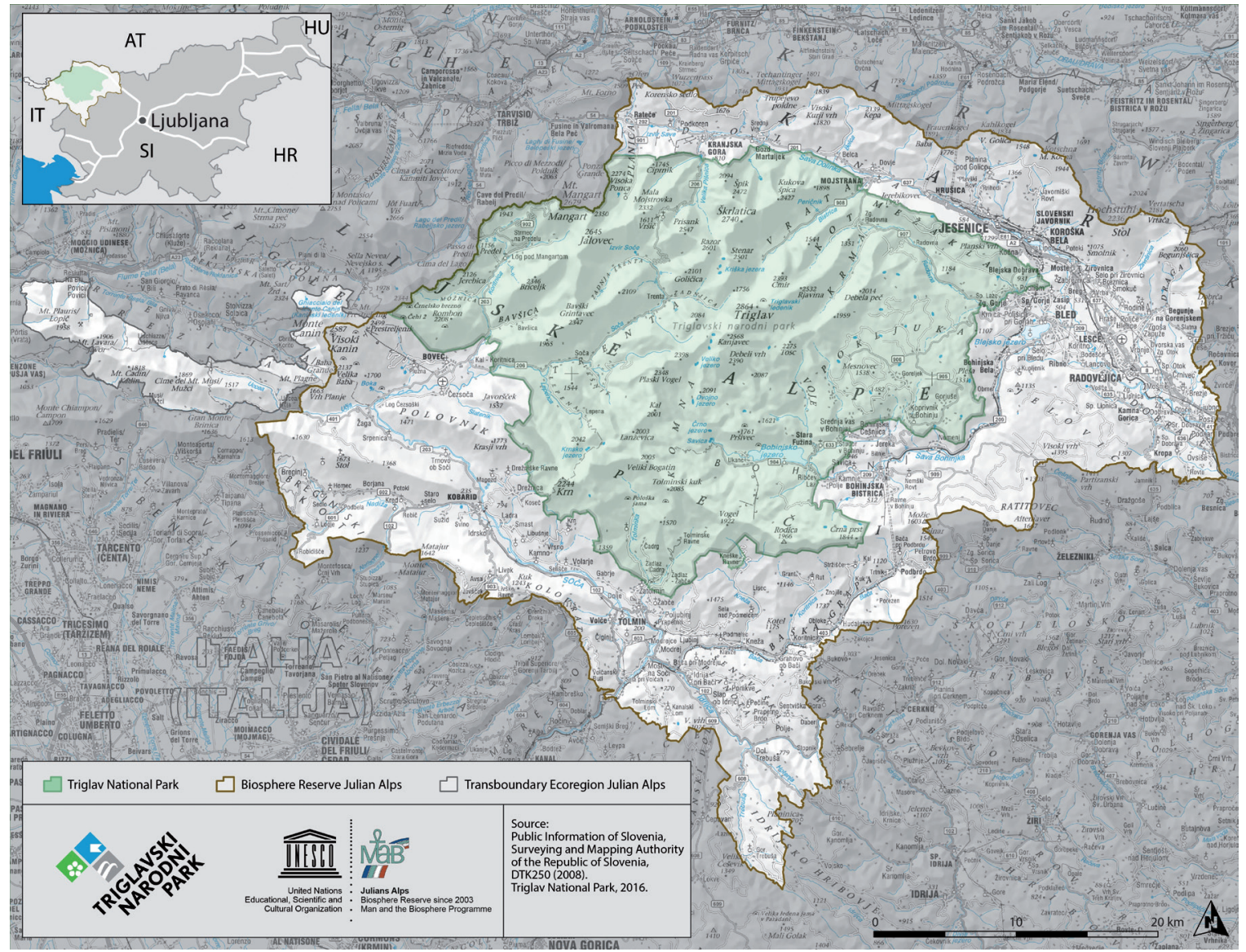

Figure $1-M A B$ Julian Alps.

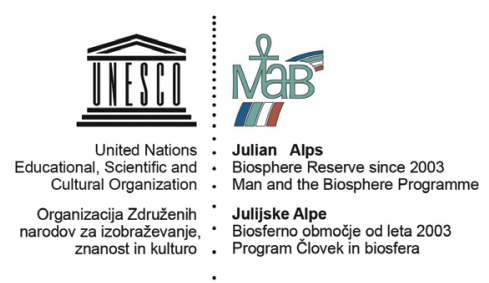

period 20152019), while the area is also one of the most popular tourist destinations in Slovenia. In

2019 it recorded 1624128 visits by Slovenian and foreign tourists $(26 \%$ of all visits to protected areas in Slovenia), and generated 4002443 overnight stays (25.35\% of all overnight stays in Slovenia). Tourism is the main driver of sustainable development of the settlements in the JABR, and the single most important source of income for people living there. In 2020, the number of overnight stays barely reached $60 \%$ of the 2019 figures due to COVID-19, but over the same period certain destinations reported an increase in daily visitors of over $30 \%$ (compared to 2019), due to the proximity of the capital and restrictions on crossing national borders.

\section{Our path to acquiring MAB designation}

The nomination was based on the 10-year research programme UNESCO - MAB 3000 years of iron industry and pastoral economy in the Julian Alps and the impact of traditional activities on the changes in ecosystems, which the TNP Authority began in 1997 with the financial sup- port of the Slovenian National Commission for UNESCO. Alongside this research programme, the TNP Authority carried out a series of high-profile activities: they published a booklet, UNESCO MAB and TNP; acquired a protected designation of origin for tolminc cheese (see Pravilnik o označbi geografskega porekla Tolminc 2003), and won the Henry Ford European Conservation Award for reconstruction of the dairy in the organic village of Čadrg (see Ogrin 2012).

\section{Presentation of good practice}

The sustainable tourism development plan

The Julian Alps community (see link in the References for Julian Alps) is an informal association of managing authorities of tourist destinations in the Julian Alps. Some (Bohinj, Kranjska Gora, the Soča Valley, Bled) are among the most visited destinations in the country. The pilot case of sustainable tourism management was based on the Development Plan for $M A B$ Julian Alps as a Sustainable Tourism Destination (see Razvojni načrt Biosfernega območja Julijske Alpe kot trajnostne turisticne distinacije 2016), which was devised in 2015 and implemented in the years that followed. The first sustainability-based plan at a national level, it focused on re-directing visitors from high-impact areas where nature conservation is at risk to lower-exposure locations. The development plan does not consider tour- 


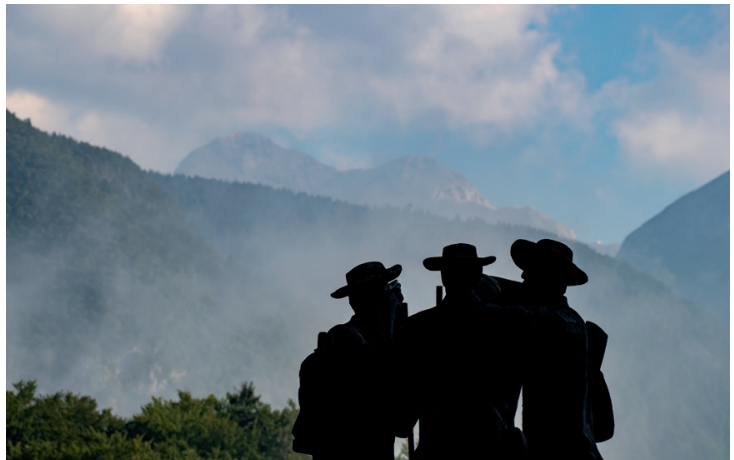

Figure 2 - Juliana Trail offering bikers spectacular views of Slovenia's highest mountain, Triglav. (C) Mitja Sodja

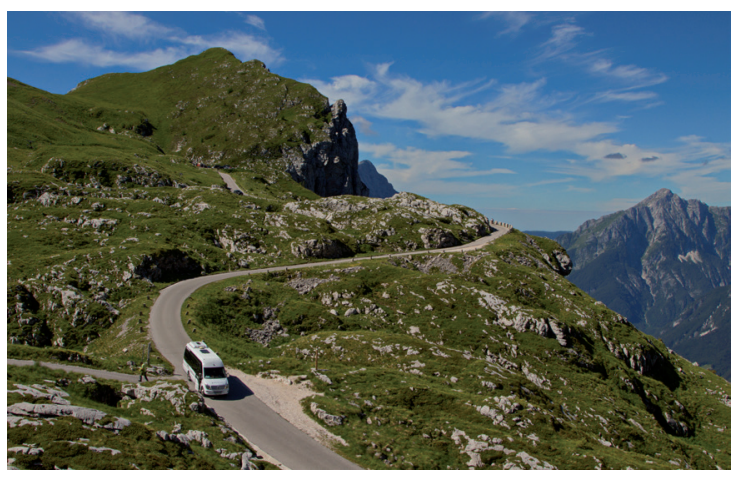

Figure 3 - Slovenia's highest-lying road - to the Mangrtsko Sedlo Pass (2122m). (C) Bostjan Odar

ism as a stand-alone activity but rather as a product of an environment that is both favourable to its inhabitants and attractive for visitors in terms of nature conservation, and environmental, social, cultural and economic aspects. Several successful products developed within the framework of the Development Plan have been introduced in recent years (e. g. the Juliana Trail), while other locations like Bled and the Vršič Pass require further procedures and measures to be put in place.

Vignette 2: The Juliana Trail

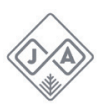

\section{JULIANA TRAIL $27 \odot / 16$}

The top priority project in the Develop-

ment Plan was the Juliana Trail, which was launched and opened to the general public in 2019 and has since attracted considerable attention. The idea of the new hiking trail was to reduce the impact of hiking tourism on Mt. Triglav by offering hikers a panoramic circular trail that runs through the transition area of TNP, opening up spectacular views of Slovenia's highest mountain and motivating hikers to choose to enjoy the magnificence of Mt. Triglav from afar (see Figure 2).

The Juliana Trail mostly runs outside the borders of TNP, through villages whose populations are shrinking due to out-migration and falling birth rates. This further increases the importance of (hiking) tourism and sales of local products (primarily foods) as a source of revenue. The 16 stages of the Juliana Trail cover 270 kilometres along existing paths, mostly through alpine valleys with well-developed infrastructure that is ideal for hiking (see link in References for Juliana Trail).

Vignette 3: Encouraging sustainable mobility in alpine valleys and over mountain passes

The traffic-reducing measures imposed in 2020 on Slovenia's highest-lying road - to the Mangrtsko Sedlo Pass (2122m) (see Mlekuž \& Mojca 2020; Triglav National Park, Public Transport in Biosphere Reserve Julian Alps 2020) - focused mainly on limiting the number of motorized vehicles (more than 20000 in 2019, which fell to less than 15000 in 2020) and available parking spaces (only 80 parking lots), organizing public transport (over 1800 passengers in the summer season of 2020, the first year of operation), and promoting hiking (see Figure 3). The project was very well received despite initial reservations, and it now provides an example of good practice for other overutilized areas. In the Lake Bohinj area (see link in the References for Tourism Bohinj), a systemic approach to encouraging sustainable mobility is already underway: motorized vehicles (primarily passenger cars) are being moved further away from the lake; pressure on the (over-)utilized starting points for high-altitude mountain hikes has been reduced; public transport connections for visitors and local inhabitants in remote locations have been improved. The innovative and comprehensive approach implemented in Bohinj is an example of sustainable mobility management in an area that is under great pressure from the volume of Slovenian and foreign visitors.

\section{The Trivlav National Park quality mark}

The JABR and TNP deliver added value in terms of nature conservation, appreciation of cultural heritage, the quality of life of local inhabitants, and the local economy. Sustainable tourism can play an important role in preserving and expanding other economic activities, primarily agriculture and crafts, while promoting self-sufficiency. Developing collective trademarks aims to enhance the creation of added value and to improve the quality of life in montane areas. The aim of the TNP Quality Mark (see link below) is to connect providers within the existing certification systems who meet the objectives of the park - i.e. who are committed to sustainable practices and ensure the high quality of their products and services (see Figure 4).

The TNP Quality Mark is awarded to the products and services of providers who understand the need to preserve nature and the environment for generations to come. It enables consumers to support the local economy and tradition; it is a sign of respect for nature and trust in people who have lived and worked here for centuries. The Quality Mark supports indigenous breeds of domestic animals such as the Drežnica goat, Bovec sheep and Cika cattle, as well as the holders of the EU protected designation of origin: the piquant mohant cheese, tolminc cow's milk cheese and 


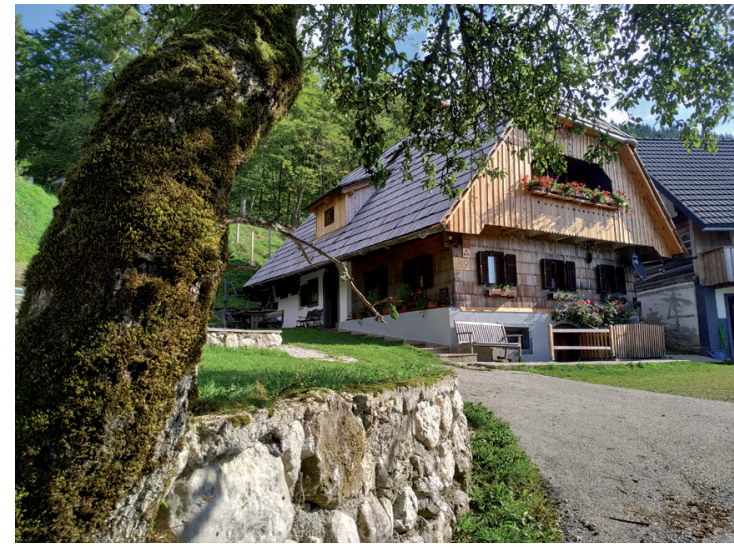

Figure 4 - TNP Quality Mark, Eco tourist farm Gorjup. (C) Archive Eco Tourist farm Gorjup

Bovški sir sheep's cheese, which all boast a long tradition and a strong local importance, and are renowned and well-loved in Slovenia and abroad.

Vignette 4: Trademarks and the TNP Quality Mark

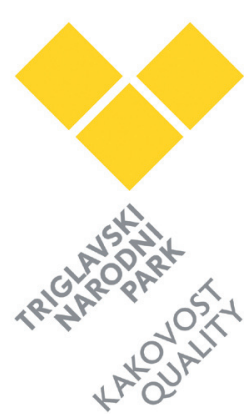

The trademarks of producers within the Julian Alps aim to improve their marketing positions, especially when the producers have been awarded the TNP Quality Mark.

As was demonstrated in 2020, collaboration among different branches of the economy (in particular in remote, sparsely populated areas) is key to the prosperity and continued balanced development of the local community. Another strong contributing factor is the merging of existing nationally and internationally recognized environmental standards, provided they comply with the objectives of UNESCO MAB and the TNP.

The standards are merged through the TNP Quality Mark certification system.

\section{Cross-border cooperation - towards a} transboundary UNESCO MAB area

The JABR is mainly a rural and montane border area. Its collaboration with cross-border areas that have similar challenges (relatively small populations and high visitor volumes) is crucial and requires a clear vision for long-term collaboration (see Transboundary Ecoregion Julian Alps, Triglav National Park with UNESCO MAB Area Julian Alps Area - Prealpi Giulie Nature Park, a new vision 2018).

Cross-border cooperation between two adjoining protected areas - TNP and the Parco Naturale Prealpi Giulie (see link below) - began soon after the Italian park was established and has grown stronger with every EU project which the parks have jointly implemented (Interreg: Palpis, ERA, Climaparks, Nat-

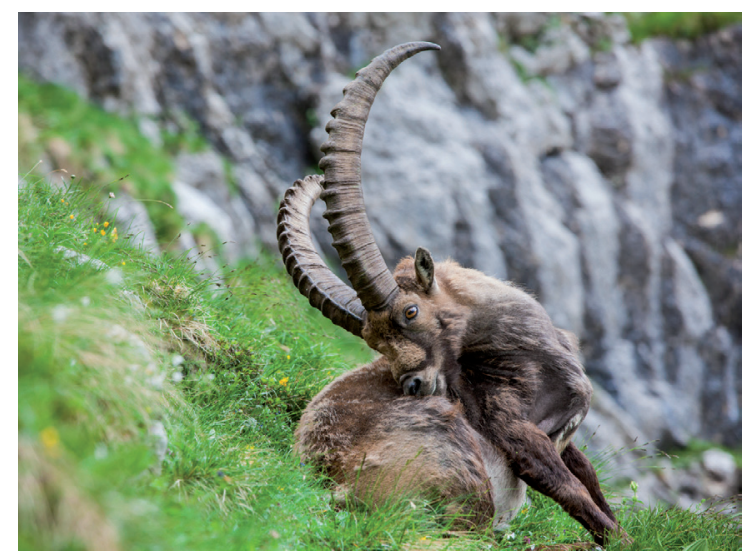

Figure 5 - Julian Alps Transboundary Ecoregion - Alpine Ibex, Archive TNP. (C) Aleš Zdešar

2care, Alpine Space: Alpencom, Alp.Bio.Net). In 2007 an initiative was launched to establish a transboundary park (stretching across national borders); two years later the Europarc Federation proclaimed the Julian Alps Transboundary Ecoregion (see link below), which includes the entire territory of the MAB Julian Alps in Slovenia and the territory of the Parco Naturale Prealpi Giulie on the Italian side of the border. The Transboundary Certificate was renewed in 2014 and 2020. The recertification, along with the observations and recommendations given, is an important recognition of what has been achieved, and a motivation and inspiration for further efforts in relation to the protection of natural and cultural heritage, visitation management, new development options, and cultural exchange among educational institutions.

Vignette 5: A transboundary biosphere resere a biosphere reserve for the future

The political systems that developed after World War II separated nations on both sides of the Slovenian-Italian border for decades. Reintroduction of the ibex in the border area of Kanin / Canin in the late 1990s laid the foundation for long and fruitful cooperation between the two border protected areas. The visionary attitude of their managing authorities, unaffected by the language barrier and different political systems, put the Julian Alps area on the map as an ecologically distinct region that actively supports ecological connectivity between BRs, and as the first transboundary area to be awarded the European Charter for Sustainable Tourism (see Figure 5).

In 2019, the Slovenian JABR was joined by the newly designated Italian JABR, with the aim of establishing a single transboundary BR.

The vision of a single transboundary BR is to ensure even better connected and better aligned management of the entire (cross-border) Julian Alps. 


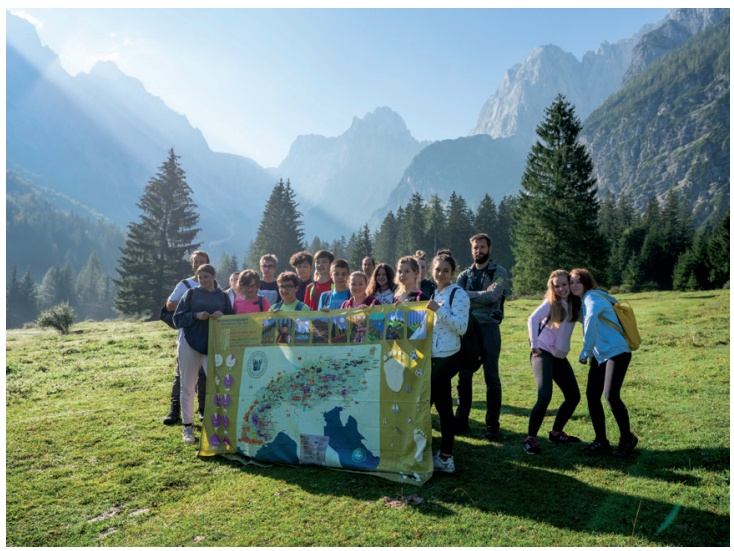

Figure 7 - Community of Schools of MAB Julian Alps - Nature Day in Kranjska Gora region. (C) Mojca Odar

Educationg the young - bringing future leaders together

Environmental education of children and young people has been a constant focus of TNP since it was established. The designation of the JABR enabled educational activities to be included in systematic programmes for primary school children, which were conducted on-site (in the natural environment), at schools, and at TNP's information centres in Bled, Bohinj and Trenta. In 2018, the Community of Schools of the JABR was founded. This was the first largescale association of primary schools and a protected area managing authority, and in a well-recognized area (the JABR). The Community of Schools is made up of 45 primary schools and brings together over 7000 pupils and teachers (Figure 6).

The TNP Authority acts as the coordinator of the Community of Schools. The long-term goal is to connect the TNP Authority with the young generation as the future leaders for the development of the JABR. The priority objectives are to raise the community's awareness of the importance of MAB, and to achieve the goals of the UNESCO network of schools.

\section{SKUPNOST ŠOL BIOSFERNEGA OBMOČJA JULIJSKE ALPE}

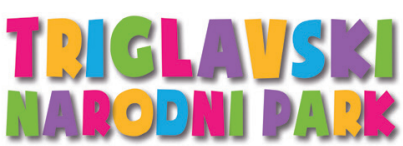

COMMUNITY OF SCHOOLSOF THE JULIAN ALPS BIOSPHERE RESERVE TRIGLAV NATIONAL PARK

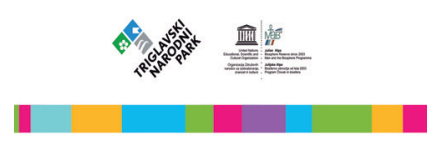

the BRs in Slovenia, sustainable development, climate change, etc. The project's website recorded more than 50000 visits in 2020, when it was founded.

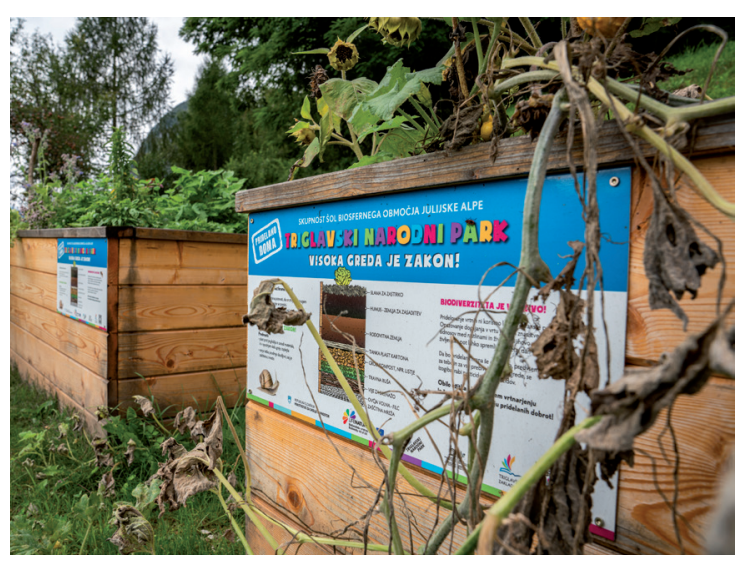

Figure 6-Community of Schools of MAB Julian Alps Raised beds to encourage the production of locally grown food (C) Mojca Odar

On-site activities: Due to COVID-19 restrictions, the 2020 summer nature science camp took the form of Nature Days (a total of 100 participants) with experts from the TNP Authority and external providers. Nature workshops are not only held for educational purposes: they are also intended for networking and building the JABR identity.

Didactic tools: each member of the Community of Schools (45 schools) received a raised bed with young plants and a plum tree sapling to encourage the production of locally grown food (see Figure 7).

Networking and collaboration: In 2020, just before the school lockdown, an online interactive event was broadcast for all pupils in grades 1 to 3 (more than 100 classes). The event was financed by the Slovenian National Commission for UNESCO.

Publication: every pupil receives the Community of Schools' newsletter. This allows the message to be spread to the pupils' parents and beyond, to an extremely wide audience.

\section{Conclusion}

The bottom-up management approach and participation of various stakeholders from the fields of tourism (destination managers), agriculture (local farmers and food-producers) and education (teachers) plays a crucial role in managing our common space - the JABR. From a historical point of view, this is a montane area subject to long-term depopulation and abandonment of settlements, but it is also a tourist destination of more than 100 years' standing. Today tourism is one of the most important industries; however, in many areas, high visitor volumes are already causing environmental and social problems. The added value of the JABR is its ability to connect the visitor management authorities and traditional economic activities of the area with educational programmes for children and young people that focus on the area's natural assets and, above all, responsible interventions in nature. 


\section{References}

Mlekuž, P. \& S. Mojca 2020. The Mangrt Road. Available at: https://www.tnp.si/assets/Publikacije/Nacudovitih-poteh-Julijskih-ALp/zlozenka-TNP-Mangrt-Road-ANG.pdf (accessed: 02/09/2021)

Ogrin, M. 2012. The Alpine Convention and its Contribution to Sustainable Development in Slovenian Alpine Areas: 91-105. Ljubljana. Available at: https:// www.researchgate.net/publication/272651007 The_Alpine_Convention_and_its_contribution_ to_sustainable_development_in_Slovenian_ Alpine_areas/fulltext/57aa774508ae7a6420bd11a 5/The-Alpine-Convention-and-its-contribution-tosustainable-development-in-Slovenian-Alpine-areas. pdf (accessed: 24/06/2021)

Pravilnik o označbi geografskega porekla Tolminc 2003. Available at: http://www.pisrs.si/Pis. web/pregledPredpisa?id=PRAV5248 (accessed: 02/09/2021)

Razvojni načrt Biosfernega območja Julijske Alpe kot trajnostne turistične destinacije 2016 - Bled. Available at: https://julian-alps.com/en/literature/catalog/ development-plan-for-the-julian-alps-biosphere-region-as-a-tourist/62455114/ (accessed: 02/09/2021)

Triglav National Park Authority 2016. Načrt upravlanja Triglavskega narodnega parka 2016-2025. Available at: https://www.tnp.si/sl/javni-zavod/nacrtupravljanja-triglavskega-narodnega-parka/ (accessed: 24/06/2021)

Triglav National Park Authority 2020. Triglav National Park, Public Transport in Biosphere Reserve Julian Alps. Available at: https://www.tnp.si/assets/ Spoznajte/Publikacije/Odkrivaj-Discover/Javniprevozi-v-Biosfernem-obmocju-Julijske-Alpe-2020. pdf (accessed: 24/06/2021)

Triglav National Park Authority and Julian Prealps Nature Park Authority 2018. Transboundary Ecoregion Julian Alps, Triglav National Park with UNESCO MAB Julian Alps Area-Prealpi Giulie Nature Park, A New Vision - Trenta. Available at: https://www.tnp.si/assets/ Partnerji/Ekoregija-Julijske-Alpe/vizija-ang-6-2018. pdf (accessed: 24/06/2021)

\section{Links}

Ecoregion Julian Alps: https://www.tnp.si/en/ learn/julian-alps-ecoregion/

Julian Alps: https://julian-alps.com/

Julian Alps Biosphere Reserve: https://www.tnp. si/en/learn/balance-between-people-and-nature/

Julian Prealps Nature Park: https://www.parcoprealpigiulie.it/

Juliana Trail: https://julian-alps.com/en/p/julianatrail/42271466/

TNP Quality Mark: https://www.tnp-kakovost.si/

Tourism Bohinj: https://www.bohinj.si/

Triglav National Park: https://www.tnp.si/

Triglav Treasury: https://triglavskazakladnica.si/

\section{Authors}

Majda Odar ${ }^{1}$ - corresponding author

Head of Information and Environmental Education, Triglav National Park Authority. E-mail: majda. odar@tnp.gov.si

\section{Renata Cerkovnik' \& Davorin Koren'}

Sustainable Development, Triglav National Park Authority; promotion of organic farming, development of Triglav National Park Quality Mark. E-mails: renata.cerkovnik@tnp.gov.si \& davorin.koren@tnp. gov.si

\section{Mojca Smolej ${ }^{1}$ \& Marko Pretner ${ }^{1}$}

Information and Environmental Education, Triglav National Park Authority; transboundary cooperation and coordination. E-mails: mojca.smolej@tnp.gov.si \& marko.pretner@tnp.gov.si

\section{Janez Bizjak}

Institut Alpe Bled, former Director of Triglav National Park Authority; author of the application for nomination as Julian Alps BR, UNESCO MAB. Inštitut Alpe Bled, Rečiška 1A, 4260 Bled, Slovenia. E-mail: bizjak.bled@siol.net

\section{Klemen Langus}

Director of Tourism Bohinj, Coordinator of the Julian Alps Community; expert in sustainable mobility, collective trademarks and sustainable tourism products. Bohinj Tourist Board, Stara Fužina 38, 4265 Bohinjsko jezero, Slovenia.

\section{Miša Novak}

Entrepreneur, tourism communications and marketing expert. Alohas, trajnostne rešitve v turizmu, s.p., Groharjeva ulica 5, 1230 Domžale, Slovenia. E-mail: misa.novak@alohas.si

\section{Slavka Zupan}

Entrepreneur, specializing in drawing up development documents. K\&Z, svetovanje za razvoj d.o.o., Kranjska cesta 4, 4240 Radovljica, Slovenia; E-mail: slavka.zupan@kz-consult.si

${ }^{1}$ Triglav National Park, Ljubljanska cesta 27, 4260 Bled, Slovenia. 